Janusz Barański

ORCID: https://orcid.org/0000-0002-6917-4557

Uniwersytet Jagielloński

Instytut Etnologii i Antropologii Kulturowej

\title{
Omówienie pracy: Grażyna Ewa Karpińska, Aleksandra Krupa-Ławrynowicz, 2019, Grembach - etnograficzny przewodnik po łódzkim osiedlu, Łódź: Wydawnictwo Uniwersytetu Łódzkiego, ss. 255
}

Odebrano / Received: 19.04.2021

Zaakceptowano / Accepted: 05.10.2021

Formuła przewodnika etnograficznego jest nowatorską propozycją Grażyny Ewy Karpińskiej i Aleksandry Krupy-Ławrynowicz, nieistniejącą bodaj nigdzie indziej w literaturze antropologicznej. Jest wersją public anthropology, antropologii publicznej, o którą od dawna apeluje Robert Borofsky, rodzajem pisarstwa antropologicznego przyjaznego czytelnikowi, który nie zdobył szlifów w tej dyscyplinie wiedzy. Ta właśnie formuła pozwala między innymi na dotarcie do szerokiego odbiorcy w propagowaniu tematów charakterystycznych dla antropologii, lecz również przekazywaniu wiedzy na temat jej specyfiki zakresowej, metodologicznej, teoretycznej. Public anthropology jest zarazem specyficzną wersją applied anthropology, antropologii stosowanej, tutaj jednak aplikowanej nie na zasadzie diagnoz eksperckich, lecz przestrzeni dialogu między badaczem a odbiorcą przekazywanej wiedzy. Daje przy tym szansę na poszerzenie wiedzy o antropologii i jej rozpowszechnianie, co jest niezwykle ważne w polskich realiach, w których dyscyplina ta, rozpoznawana wciąż głównie pod nazwą „etnografia”, kojarzona jest nieodmiennie z Kolbergiem, dawniejszą Cepelią i być może współczesnym disco polo. 
„Etnograficzny przewodnik” jest nie tylko rozprawą antropologiczną, lecz również zasobem bardzo rzeczowej wiedzy cenionej przez miłośników krajoznawstwa (historia dzielnicy, historyczne plany, szata roślinna itd.), może zatem zaspokoić ciekawość pasjonata lokalnej historii, geografii czy botaniki. Uwzględniono jednak i inne, ważniejsze z antropologicznego punktu widzenia sfery życia dzielnicy i jej mieszkańców. Ujawnia się to w prezentacji życia rodzinnego i publicznego, aktywności gospodarczej, pracy, handlu, czasu wolnego, rozrywek kulturalnych, urbanistyki, architektury i innych sfer życia przedstawionych w ciągu historii Grembacha sięgającej XIX wieku. Załączone liczne zdjęcia ukazują przy tym tak mało znaną urokliwość Łodzi, która - odwrotnie do tego wizerunku - zwłaszcza w ostatnich dekadach pełniła dyżurną rolę polskiego Detroit, miasta upadłego, zrujnowanego, brzydkiego. Lecz nietknięte zębem czasu „kocie łby" starych ulic, pamietających jeszcze niemieckich mieszkańców miasta, w których języku należy upatrywać etymologię nazwy dzielnicy, ręczne pompy uliczne, niewielkie kamieniczki przeczą temu stereotypowi. Tutaj autorki wywiązały się rzetelnie z jednego z zadań antropologa - między innymi podważania opacznych opinii, klisz, uprzedzeń, utartych wizerunków.

Pewna część pracy poświęcona jest historii dzielnicy, prezentowana w niezwykle drobiazgowy i wszechstronny sposób. Dotyczy to zwłaszcza dziejów najnowszych, których poznanie antropolog zawdzięcza nie tylko archiwom, lecz i częstokroć naocznym świadkom. Do perełek informacji o nie tak przecież odległej historii, jakim było na przykład międzywojnie, należy choćby wzmianka o fakcie zbudowania kilku domów robotniczych $\mathrm{z}$ rozebranego ceglanego komina fabrycznego. To jeden $\mathrm{z}$ jakże ważnych elementów niełatwego życia codziennego klasy pracującej tamtej doby, pokazujący zarazem oddolność rozmaitych inicjatyw, samopomoc, taktykę radzenia sobie, jak powiada Michel de Certeau, do którego znajdziemy tutaj odwołania. I słusznie, w końcu „przewodnik" skupia się na badaniu codzienności, co było też przedmiotem głównego zainteresowania słynnego francuskiego badacza.

Czytelnik może mieć silne wrażenie emocjonalnej więzi badaczek i zarazem narratorek z miastem i przedstawianą dzielnicą, gdzie odrapane, podupadające kamieniczki, dawne i współczesne kuchnie i inne wnętrza mieszkalne, przydomowe ogródki ukazywane są $\mathrm{w}$ kadrze fotograficznym oraz w słowie komentarza niemal z czułością. Nie bez związku z tym pozostaje mrówczy charakter pracy archiwalno-etnograficzno-socjologicznej wykonanej przez Karpińską i Krupę-Ławrynowicz. Na osobną uwagę zasługuje współczesna dokumentacja fotograficzna - ilustracja wizualna prezentowanej dzielnicy. Czujnemu oku etnografa nie umykają najdrobniejsze szczegóły dokumentujące życie codzienne dzielnicy: zieleń, estetyka, graffiti, wnętrza mieszkalne, detale architektoniczne, przydomowe ogródki, podwórka ... Chciałoby się rzec, iż autorki zaglądają niemal w każdy kąt, nie pomijają niczego i robią to z pasją.

W „etnograficznym przewodniku” nie mogło zabraknąć wymiaru społecznego życia dzielnicy: stosunków narodowościowych, tak silnie obecnych w krajobrazie 
kulturowym Łodzi aż po wybuch II wojny światowej, historii rodzinnych, stosunków sąsiedzkich, relacji z mieszkańcami innych dzielnic, obyczajowości, życia towarzyskiego.

Mimo swojego „przewodnickiego” charakteru praca jest na wskroś antropologiczna. Wprawdzie dominuje w niej warstwa opisowa (lecz najlepszego etnograficznego szlifu), obecne są jednak niezbędne odwołania do klasyki myśli filozoficznej, socjologicznej, antropologicznej, folklorystycznej, która z powszedniej codzienności uczyniła pole badawcze o najwyższym potencjale kreowania ludzkich światów (m.in. koncepcje Simmela, de Certeau, Geertza, Kowalskiego). Autorki świadomie posługują się tutaj określeniem „miejska kultura ludowa”, zapożyczonym od Pierre’a Mayola, którego rozumienie kultury robotniczej pojawia się $\mathrm{w}$ pracy. Zresztą wyłożone $\mathrm{w}$ niej rozumienie codzienności klasy pracującej można uznać za polski odpowiednik koncepcji francuskiego badacza.

Praca wykonana przez Karpińską i Krupę-Ławrynowicz, przedstawiona na kartach „Grembachu”, jest lokalną wersją projektu badań kultury robotniczej, zainicjowanego z górą pół wieku temu przez Richarda Hoggarta. Jego ważne dzieło o kulturze angielskiej klasy pracującej nie wyszło jednak zasadniczo poza własne wspomnienia badacza, wyrosłego $\mathrm{w}$ tym środowisku, ubrane wszakże $\mathrm{w}$ interesująca szatę literacką, którą Hoggart jako literaturoznawca nadał swojemu dziełu. Autorki „etnograficznego przewodnika" nie tylko wyszły poza ujęcie historyczne czy wspomnieniowe podobnej problematyki, to jeszcze uzbrojone $\mathrm{w}$ metodologię badań etnograficznych pozyskały $\mathrm{w}$ trakcie pracy terenowej bezpośrednie informacje o tejże historii, równocześnie rysując kształt środowiska robotniczego - przed rokiem 1989, a post-robotniczego dziś. Zarazem posłużyły się archiwalnymi metodami badań (dokumenty, prasa, fotografie itp.), dokonując dzięki temu gruntownego wysycenia danych empirycznych, które dodatkowo podlegają dzięki temu w większym stopniu weryfikacji, tutaj niejako samoistnej, na poziomie faktograficznym. To zresztą pozwala na uchwycenie przemian, jakie miały miejsce w ciągu XX wieku, czego miłośnik Łodzi sięgający po „Przewodnik” po Grembachu czy jakiejś innej ekumenie nie znajdzie w podobnej acz standardowej wersji (możliwe zresztą, że takowego po prostu nie ma). Rzecz to ważna z punktu widzenie poprawności metodologicznej humanistyki, natomiast $\mathrm{w}$ przypadku antropologii pierwszorzędna. Tutaj autorki preferowały warstwę rzeczywistości szczególnie ważną z antropologicznego punktu widzenia, sferę światów wyobrażonych domagającą się rekonstrukcji i/lub dekonstrukcji za sprawą szkiełka i oka badacza. To te właśnie światy okazują się światami prawdziwymi w tym rozumieniu, że dzięki obecności podzielanych wartości, norm, znaczeń ich subiektywność obiektywizuje się, poprzez podzielanie pewnego światoobrazu staje się subiektywnie rzeczywista, jak by uznali Berger i Luckmann.

Autor:

Prof. dr hab. Janusz Barański

e-mail: j.baranski@iphils.uj.edu.pl 
